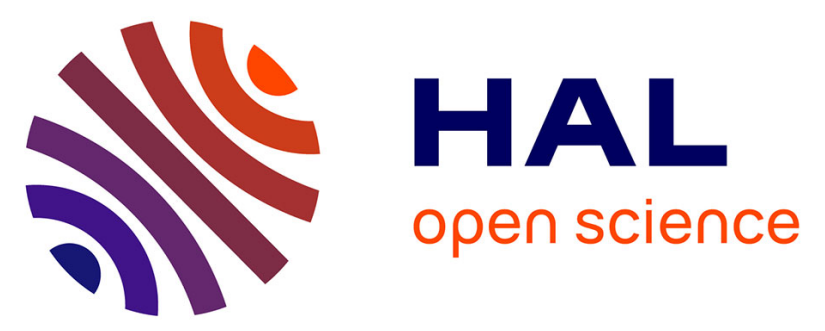

\title{
Use of mixing models to explain groundwater quality time and space variation in a narrowed fluctuating alluvial aquifer
}

\author{
Julien Jean-Baptiste, Corinne Le Gal La Salle, Patrick Verdoux
}

\section{To cite this version:}

Julien Jean-Baptiste, Corinne Le Gal La Salle, Patrick Verdoux. Use of mixing models to explain groundwater quality time and space variation in a narrowed fluctuating alluvial aquifer. Applied Geochemistry, 2020, 121, pp.104700. 10.1016/j.apgeochem.2020.104700 . hal-02923031

\section{HAL Id: hal-02923031 \\ https://hal.science/hal-02923031}

Submitted on 26 Aug 2020

HAL is a multi-disciplinary open access archive for the deposit and dissemination of scientific research documents, whether they are published or not. The documents may come from teaching and research institutions in France or abroad, or from public or private research centers.
L'archive ouverte pluridisciplinaire HAL, est destinée au dépôt et à la diffusion de documents scientifiques de niveau recherche, publiés ou non, émanant des établissements d'enseignement et de recherche français ou étrangers, des laboratoires publics ou privés. 


\title{
Use of mixing models to explain groundwater quality time and space variation in a narrowed fluctuating alluvial aquifer
}

\author{
Julien Jean-Baptiste *, Corinne Le Gal La Salle, Patrick Verdoux \\ Univ. Nûmes, EA 7352 CHROME, rue du Dr Georges Salan, 30021, Nûmes, France
}

\section{A R T I C L E I N F O}

Editorial handling by Prof. M. Kersten

\section{Keywords:}

Groundwater quality

Time and space variations

Multiple contributors

Major ions water stables isotopes survey

PHREEQC inverse Modeling

GLUE-EMMA conservative Modeling

Mixing process

Reactive process

\begin{abstract}
A B S T R A C T
Hydrogeochemical studies can provide insights to pursue a flexible and responsive groundwater resources management.Origin of water, mixing and reactive processes are three key parameters that allow to understand hydrological systems and resulting groundwater quality.However, those parameters may evolve strongly and quickly over time and space, especially for hydrological system impacted by pumping activities and seasonal variations. Within this framework, the current study aims to pursue a survey of the hydrological parameters in a small dynamic alluvial aquifer fed by 3 contrasted end-members and used for water supply. The variations of the end-members and the alluvial groundwaters quality $\left(\mathrm{Ca}^{2+}, \mathrm{Mg}^{2+}, \mathrm{K}^{+}, \mathrm{Na}^{+}, \mathrm{Cl}^{-}, \mathrm{CO}_{3}^{2-}, \mathrm{NO}_{3}^{-}, \delta^{2} \mathrm{H}\right.$ and $\left.\delta^{18} \mathrm{O}\right)$ will be used as a record of those parameters. 26 sampling campaigns were carried out fortnightly from October 2017 to October 2018 and data processed with two distinct mixing models: GLUE-EMMA model, which define likelihood of each mixing component, and PHREEQC inverse modeling, which account for the reactive processes that occur as water chemistry evolves. For each studied groundwater, appropriate time variant end members signatures as well as analytical uncertainties were accounted and models constrained to fit within $5.0 \%$ for the major ions and $0.5 \%$ for water stable isotopes. With suitable models for all alluvial groundwater samples, both GLUE-EMMA and PHREEQC highlight the mixing process between two end-members as the main parameter of the alluvial groundwater quality. Nonetheless, $\mathrm{Mg}^{2+}$ and $\mathrm{K}^{+}$reactive fluxes are needed to fit with the required constraints.Hence, the alluvial groundwater quality variations are either associated with the typical seasonal variations of the end-member signature and the change of the mixing processes.For both models, mixing process exhibits slow and small as well as strong and sudden changes. The first can be related with the relative capacity of the end members to feed the aquifer according to their individual high and low water periods. The second to the effects of alternative pumping regime between sampling campaign. The capacity of both models to evaluate and monitor main hydrological processes, over time and space, confirms the interest to combine them as a flexible multi process investigation suited for dynamic hydrological system.
\end{abstract}

\section{Introduction}

In France, groundwater constitutes approximatively $62 \%$ of the domestic water supply. Alluvial aquifers constitute an accessible and easily renewed resource, recharged by surface water, and providing water supply with more than 1500 million of $\mathrm{m} 3$ of water withdrawal per year (Margat, 2006). Around 10 million people depend on this resource and since the beginning of the last century, quality and quantity pressures have been increasing (Scanlon et al., 2007; Schwartz and Ibaraki, 2010). Nevertheless, these resources are vulnerable to contamination (Lap. worth et al., 2012). Identification and neutralization of the ways in which human activities impact on those systems are essential to the resource management strategies (Jakeman et al., 2016). Emerging risks, such as presence of organic contaminants and climate change impacts (Scheili et al., 2016b; Pereira et al., 2015) requires further understanding of the hydrological system functioning for suitable management.

The origin of the water, mixing processes and reactive processes are three key parameters that allow to understand hydrological systems and resulting groundwater quality.

However, those parameters may evolve strongly and quickly over time and space in an environment impacted by pumping activities and seasonal variations. The current manuscript presents a methodology and its application to identify processes and quantify contributions from

\footnotetext{
* Corresponding author.

E-mail address: julien.jean-baptiste@unimes.fr (J. Jean-Baptiste).
} 
different endmembers.

A small dynamic alluvial aquifer will be investigated and variations of the waters quality will be used as records of those varying processes. To identify and rank the hydrological processes, those records will be processed in two distinct mixing models:

- GLUE-EMMA model (Delsman.,2013) which define likelihood of all plausible sets of end members conservative mix.

- PHREEQC inverse modeling which account with the chemical changes that occur as water chemistry evolves in a reactive environment.

The successful application of both models will confirm the interest to deploy this methodology as a flexible multi process investigation.

\section{Study area characteristics}

\subsection{Geographical settings}

In this study, we focused on the investigation of the Comps aquifer system. Used for the Nîmes township water supply, Comps aquifer is located in the south of France ( $50 \mathrm{~km}$ north of Mediterranean Sea) at the immediate confluence of two rivers: the Rhone and the Gardon. The Rhone river is one of the major European rivers with a drainage area of $98800 \mathrm{~km}^{2}$ (Fig. 1); it flows $810 \mathrm{~km}$, from its source in Switzerland, through urbanized, and industrial environments along major cities (Genève, Lyon, Valence, Montélimar, Avignon and Arles) before ultimately reaching the Mediterranean Sea. In contrast, with a drainage area of $2000 \mathrm{~km}^{2}$, the Gardon river flows $127 \mathrm{~km}$ in a preserved, rural environment before reaching the Vallabregues hydroelectric dam, where it mixes with the Rhône river.

\subsection{Geological settings}

Comps aquifer is a $400 \mathrm{~m}$ wide and $1200 \mathrm{~m}$ long shallow alluvial aquifer. The aquifer is bordered on the East by an arm of the Rhone river just after its confluence with the Gardon river and on the West by a cretaceous limestone massif outcropping and plunging Eastward (Mont Aiguille). The Comps aquifer consists of $15 \mathrm{~m}$ of Holocene alluvial materials deposited by the Rhone and Gardon valley, the Comps aquifer is covered by $5 \mathrm{~m}$ of loam and lies on a $200 \mathrm{~m}$ thick impermeable Plaisancien loam formation.

On a regional scale, the studied area (Fig. 1) presents contrasted outcrop geological domains. This layout is explained by the following geological events:

- During the Pyrenean orogeny phase over the Eocene (136-130 Ma), the regional cretaceous limestones is folded and fractured. (Benedicto et al., 1996; Séranne et al., 1995).
- During the Miocene stage, those cretaceous limestones are partially recovered by the peri alpine sea resulting calcareous molass formation deposit.

- During the upper Miocene, the Messinian crisis scoured the preRhône valley accompanied with detritic deposits.

- During the Pliocene, the pre-Rhône valley gradually evolves into a Ria filled with Plaisancien clay deposit which constitutes the substratum layer for Comps aquifer.

- Finally, this 200-m-thick impermeable layer is overlain by Quaternary and Plio detritic and sand formations. This alluvial formation constitutes the Comps aquifer.

\subsection{Hydrological and hydrogeological settings}

Comps alluvial groundwater level varies between six and $10 \mathrm{~m}$ below ground surface. The water level variation is mainly due on one hand to the continuous pumping for drinking water supply, and on the other hand, to the strong hydraulic connection between the aquifer and the surface water level (Plagnes, 1994):

- Pumping rate varies between 1600 and $2000 \mathrm{~m}^{3} / \mathrm{h}$ according to the demand (day/night cycles; summer tourism inflow).

- At the river's confluence location, the water level of the Rhône arm is artificially controlled by the Vallabregues hydroelectric dam situated just upstream of the confluence (Fig. 1) while the Gardon's water levels varies according to the seasons.

Comps aquifer does not receive direct rainfall recharge due to an impermeable loam deposit occurring during historic river floods. Nevertheless, the groundwater level remains below the impermeable deposit and the groundwater is unconfined.

The groundwater main natural flow direction is North-South, parallel to the surface water flow direction. The aquifer permeabilities may vary significantly from $1.5 \times 10^{-2}$ to $3.8 \times 10^{-4} \mathrm{~m} / \mathrm{s}$ due to local alluvial material heterogeneity.

As discussed by Plagnes (1994), western adjacent limestone massif hosts a karst aquifer. Its interaction with the Comps alluvial aquifer was previously investigated on the basis of pumping tests, flow analyses and geochemical analyses. Results show a potential recharge of the alluvial aquifer by the karst groundwater.

\section{Materials and methods}

Based on an annual survey, geochemical and isotopic signatures of the Rhône, the Gardon surface waters, the limestone massif and Comps aquifer groundwaters are defined. The Comps groundwaters quality will be first investigated with Principal Component Analyses (PCA) and binary diagrams. Then two mixing models will be processed to evaluate the importance of mixing and reactive processes over time and space.

Table 2

Darcy velocities estimate from each end-members.

\begin{tabular}{|c|c|c|c|c|c|c|c|c|c|}
\hline & \multirow[t]{2}{*}{ Boreholes } & \multirow[t]{2}{*}{ Distance from endmember } & \multirow[t]{2}{*}{ Permeability (m/s) 1993} & \multicolumn{2}{|c|}{$\begin{array}{l}\text { Average hydraulic } \\
\text { gradient }\end{array}$} & \multicolumn{2}{|c|}{ Water velocity $(\mathrm{m} / \mathrm{s})$} & \multicolumn{2}{|c|}{ Transfer time (days) } \\
\hline & & & & Low flow & High flow & Low flow & High flow & Low flow & High flow \\
\hline \multirow[t]{5}{*}{ Surface waters } & PN4 & 65 & $1.8 \mathrm{E}-03$ & 7.7E-02 & $1.2 \mathrm{E}-01$ & $6.9 E-04$ & $1.0 \mathrm{E}-03$ & 1 & 1 \\
\hline & PA1 & 70 & 4.3E-03 & $5.7 \mathrm{E}-02$ & $1.0 \mathrm{E} \cdot 01$ & $1.2 \mathrm{E}-03$ & $2.1 \mathrm{E}-03$ & 1 & 0.4 \\
\hline & PNORD & 45 & $3.1 \mathrm{E}-03$ & $4.4 \mathrm{E}-02$ & $1.1 \mathrm{E}-01$ & $6.9 \mathrm{E}-04$ & $1.7 \mathrm{E}-03$ & 1 & 0.3 \\
\hline & PN5 & 140 & $2.0 \mathrm{E}-03$ & 4.3E-02 & $5.7 \mathrm{E}-02$ & $4.3 \mathrm{E}-04$ & $5.7 \mathrm{E} \cdot 04$ & 4 & 3 \\
\hline & PN7 & 170 & 9.7Е-04 & 3.2E-02 & $4.7 \mathrm{E}-02$ & $1.5 \mathrm{E}-04$ & 2.3E-04 & 13 & 9 \\
\hline \multirow[t]{5}{*}{ Limestone groundwaters } & PN4 & 230 & $1.8 \mathrm{E}-03$ & $1.7 \mathrm{E}-02$ & $2.4 \mathrm{E}-02$ & $1.6 \mathrm{E}-04$ & $2.2 \mathrm{E}-04$ & 17 & 12 \\
\hline & PA1 & 270 & 4.3E-03 & $7.8 \mathrm{E}-03$ & $1.5 \mathrm{E}-02$ & $1.7 \mathrm{E}-04$ & $3.2 \mathrm{E}-04$ & 19 & 10 \\
\hline & PNORD & 140 & 3.1E-03 & $1.2 \mathrm{E}-02$ & $1.5 \mathrm{E} \cdot 02$ & $1.9 \mathrm{E}-04$ & 2.3E-04 & 9 & 7 \\
\hline & PN5 & 160 & $2.0 \mathrm{E}-03$ & 2.5E-02 & 3.1E.02 & $2.5 \mathrm{E}-04$ & $3.1 \mathrm{E}-04$ & 7 & 6 \\
\hline & PN7 & 190 & $9.7 \mathrm{E}-04$ & $1.3 \mathrm{E}-02$ & 3.0E-02 & $6.4 \mathrm{E}-05$ & $1.5 \mathrm{E}-04$ & 34 & 15 \\
\hline
\end{tabular}




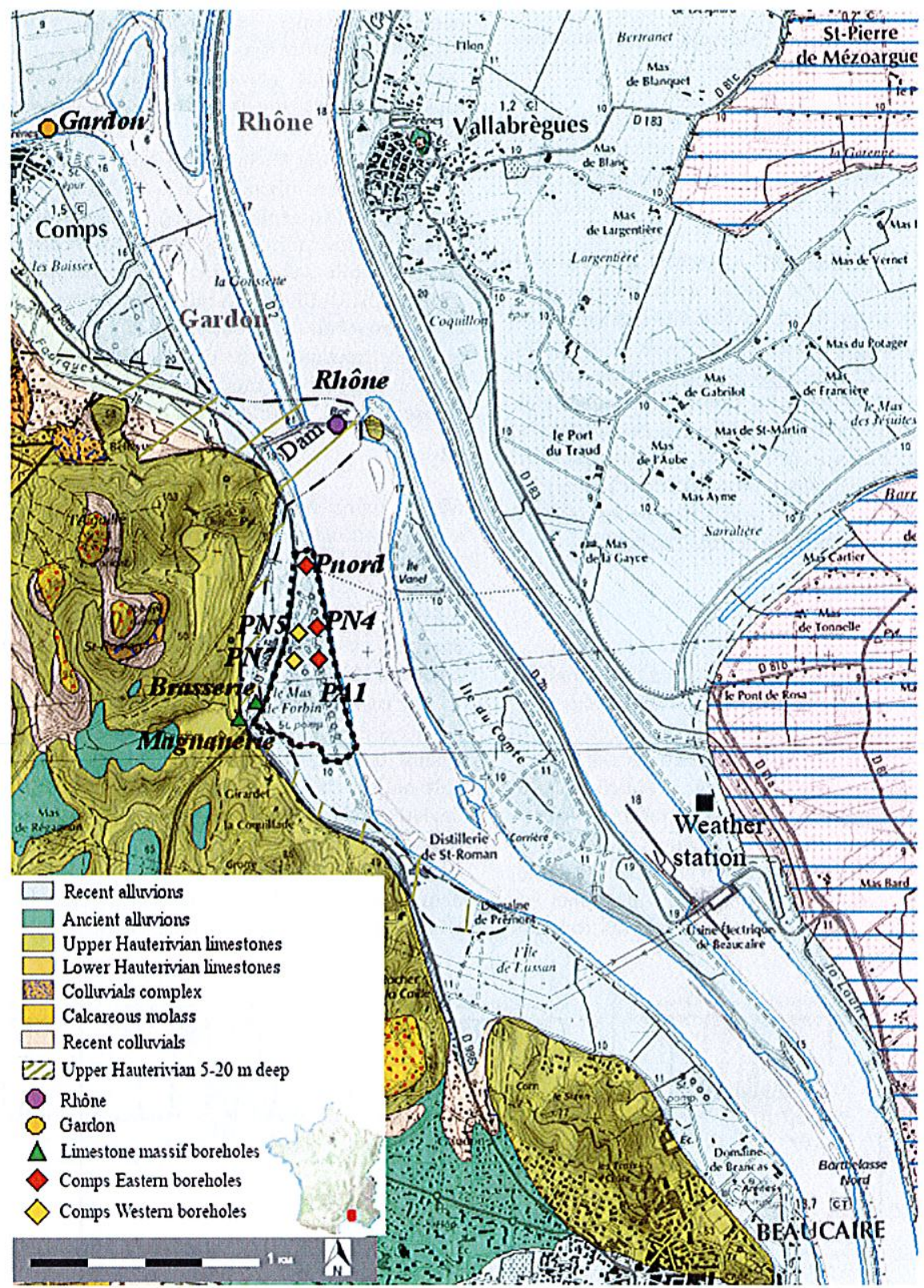

Fig. 1. Studied area geological description and sample site locations. 
deviation).

All major elements and isotopic analyses were carried out at the Laboratory of Environmental Isotope Geochemistry, University of Nîmes, EA 7352 CHROME.

With the same pumping regime configuration for each samplin campaign, groundwater samples were collected from five different boreholes in the Comps alluvial aquifer: three on the eastern side of the aquifer (Pnord, PN4 and PA1), situated approximately $60 \mathrm{~m}$ from the banks, and two on its western side (PN5 and PN7), approximately $160 \mathrm{~m}$ from the bank and $100 \mathrm{~m}$ from the Limestone outcrop. Surface water samples were collected both in the Rhône and the Gardon rivers. The limestone massif groundwaters were collected in two boreholes about $200 \mathrm{~m}$ south east of the well field (Brasserie, Magnannerie). 26 sampling campaigns were carried out fortnightly from October 2017 to October 2018 in order to cover a full hydrological year.

Before collecting groundwater samples, physico-chemical parameters (temperature, $\mathrm{pH}$, oxydo-reduction potential, specific conductance at $25^{\circ} \mathrm{C}$ and dissolved oxygen) were measured in the field with a WTW multi 3630 in a flow through cell to prevent contact with the atmosphere.

Alkalinity was measured in the field with a Hach SL1000 portable analyzer or in laboratory the very same day by volumetric titration (0.16 N H2SO4) using a Hach Lange titrator. Alkalinity standards yielded to the same results when analyzed with both methods. $40 \mathrm{~mL}$ of the samples were filtered with a $0.22 \mu \mathrm{m}$ cellulose acetate filter and dispatched in two $11 \mathrm{~mL}$ polyethylene tubes for cations and anions analysis. In order to avoid carbonate mineral precipitation cation samples were acidified to $\mathrm{pH} 2-3$ with ultrapure $\mathrm{HNO}$. Raw water was collected in $10 \mathrm{~mL}$, glass bottles avoiding air bubbles, for $\delta^{18} \mathrm{O}$ and $\delta^{2} \mathrm{H}$ analyses. Surface water samples followed the same protocol after being collected in a rinsed bucket thrown approximately $10 \mathrm{~m}$ from the banks.

\subsection{Analytical methods}

Major elements $\left(\mathrm{Ca}^{2+}, \mathrm{Mg}^{2+}, \mathrm{Na}^{+}, \mathrm{K}^{+}, \mathrm{Cl}^{-}, \mathrm{SO}_{4}^{2-}\right.$, and $\left.\mathrm{NO}_{3}^{-}\right)$analyses were carried out on ion chromatography (METHOHM 930 Compact IC Flex) with five percent uncertainties measurement (used later as standard deviation). The $\delta^{18} \mathrm{O}$ and $\delta^{2} \mathrm{H}$ isotopes compositions were determined by cavity ring down spectrometry using a Picarro L2130i according to the analytical scheme recommended by the IAEA (Penna et al., 2010). $\delta^{18} \mathrm{O}$ and $\delta^{2} \mathrm{H}$ values are reported in per mil (\%o) relative to the V-SMOW2 (Vienna Standard Mean Ocean Water) reference material, and calibrated with the internal laboratory standards. Maximum uncertainties are respectively 0.25 and $0.5 \%$ (used later as standard

\subsection{Mixing models}

\subsubsection{GLUE-EMMA conservative mixing model}

As described in Delsman et al. (2013) work, the Generalized Likelihood Uncertainty Estimation End-Member Mixing Analysis (GLUE-EMMA) tool is a conservative mixing model which can take into account multiple parameter sets (random end-members, random tracers). It leads to the likelihood of the contribution for each considered end-member.

In EMMA, the Euclidean distance between end-members and their projection in the mixing space is used as a measure of the ability of the end-members to explain mixing water concentrations. GLUE-EMMA's approach allows for varying end-member combinations to find suitable models, while taking into account the time-variant data of endmembers. A GLUE-EMMA mixing model consists of: (1) a combination of end-members as a subset of all possible end-members, (2) endmember fractions, and (3) end-member tracer concentrations. A GLUE-EMMA mixing model follows the notation of Christophersen and Hooper [1992], represented in matrix by (1):

$l_{i} \mathbf{B}=x_{i}$

where $\mathrm{l}_{\mathrm{i}}$ represents the $\mathrm{k}$ sized row vector of end-member fractions, $\mathrm{B}$ the $\mathrm{k} \times \mathrm{p}$ sized matrix of end-member concentrations, and $\mathrm{x}_{\mathrm{i}}$ the $\mathrm{p}$ sized vector of tracer concentrations in the mixing water sample, with $k$ and $p$ as the number of end-members and tracers, respectively. End-member fractions are sampled from a uniform distribution, yielding a uniform distribution of mixtures while ensuring mass balance closure (endmembers always sum to one).

For each separate mixed water sample, a large number of mixing models are generated by uniform Monte Carlo sampling and evaluated against the observed concentrations. Simulations are considered suitable only if calculated values for all tracers fall within one standard deviation of the analytical value. Distribution of suitable models are considered uniform. Likelihoods are rescaled to sum to unity over the ensemble of behavioral models identified for each time step independently. Finally, end members contributions likelihoods are described with median, inter quartile and 5-95 percentile range. All software and

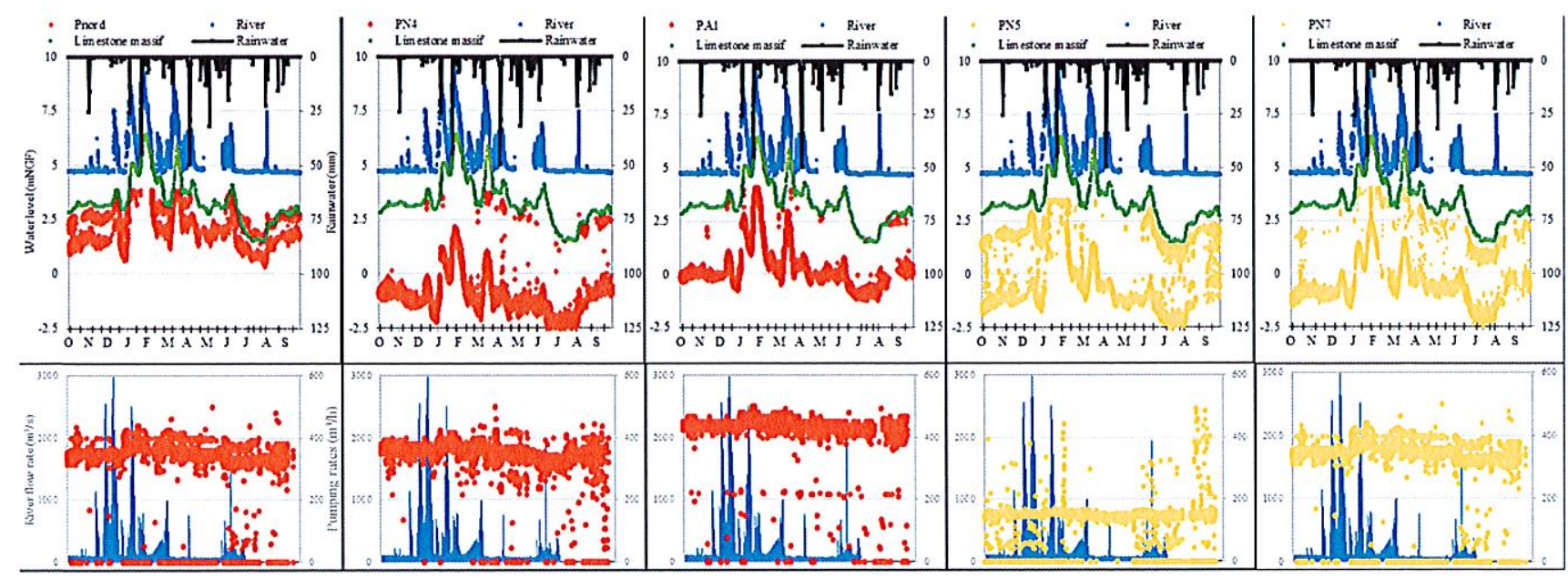

Fig. 2. a) Water levels of river (blue), limestone massif (green) and Comps boreholes (red/yellow) are displayed on principal axis, precipitation (black) are displayed on secondary axis, sampling campaign dates are represented with crossed marks on horizontal axis; b) river flow rate (blue) and borehole pumping rate (red/yellow) are displayed on primary and secondary axis. (For interpretation of the references to color in this figure legend, the reader is referred to the Web version of this article.) 
source code written to facilitate the GLUE-EMMA's procedure are available for download at http://g-emma.deltares.nl/.

\subsubsection{PHREEQC reactive inverse model}

Inverse modeling using Geochemical PHREEQC allows, in addition to mixing, to account for the chemical changes that occur as water chemistry evolves in a reactive environment between two points of observation. The basic approach in inverse modeling is to solve a set of reactions that account for the changes in the concentrations of each elements due to reactive processes, including dissolution, precipitation of minerals, exchange, sorption ..., respecting the ionic balance (Garrels and Mackenzie, 1967; Parkhurst, 1999).

Inverse models compute fractions of the defined end members and mole transfers of a defined elements that produces the composition of a studied solution. The inverse model is considered acceptable when the simulated solution respects ionic balance and uncertainty limit for each element, according to PHREEQC inputs parameters.

\section{Results}

\subsection{Comps aquifer hydrological configuration}

Water production monitoring network provides records of the Comps aquifer water table levels, boreholes' production rate and surface water level (the Rhone river height, along the alluvial aquifer). In addition to that well field monitoring network, the height of the water table in the karst aquifer is measured using a pressure sensor at the Brasserie borehole while local rainwater is measured at the closest weather station (Fig. 1). Recorded data over the studied period are displayed below (Fig. 2):

In the winter period, the river flow rate is high with an average of $1800 \mathrm{~m}^{3} / \mathrm{s}$ and significant variations reaching punctually $3000 \mathrm{~m}^{3} / \mathrm{s}$. From spring to fall, the average flow drops dramatically to 20 from 100 $\mathrm{m}^{3} / \mathrm{s}$. These variations of the flow rate are accompanied by fluctuations in water levels. The height of the Rhône river range from $4.8 \mathrm{~m} \mathrm{NGF}$ during low flow and up to $9.3 \mathrm{~m} \mathrm{NGF}$ during peak flow. It can be seen that for the year 2017-2018, the low water period of the Rhone extends from April to October while the high water period extends from December to March. The latter is composed of several recharge events, the most important of which take place in January and February. Regarding the Comps boreholes, the monitoring of pumping rates shows an almost continuous operation over the studied period. PN4 and PA1 are particularly concerned with an average and even pumping rate throughout the period of 360 and $450 \mathrm{~m}^{3} / \mathrm{h}$ respectively. Pnord, PN5 and PN7 boreholes, are more frequently concerned with short inactive period over the studied period. Nevertheless, theses boreholes are all actively pumping on each day of the sampling campaign with an average pumping rate of 130,150 and $340 \mathrm{~m}^{3} / \mathrm{h}$ respectively. Under pumping conditions, the boreholes groundwater table levels vary, from -3 to +4 $\mathrm{m}$ NGF depending on the borehole location. While under non pumping conditions, the water table rises approximately by $2 \mathrm{~m}$ for PN5 and PN7 and $1 \mathrm{~m}$ for Pnord, and up to two to $3 \mathrm{~m}$ for PN4 and PAI on the rare occasions when the pump stops. Beside the pump influence, in all cases, the Comps aquifer water levels varies concomitantly with the surface water level. The limestone groundwater levels vary between 1.5 and $6 \mathrm{~m}$ NGF along surface water fluctuations. This relation suggests the existence of a hydraulic continuity between the limestone massif by the surface waters as suggested by Plagnes (1994). Investigations witnessed the presence of limestone at a shallow depth under the alluvial deposits of the Rhone close to the Vallabregues dam (Fig. 1). Local rainwaters are ruled by the Mediterranean regime. With low numbers precipitation events occurred over the studied period, they fan out with a dry summer-autumn period $(130 \mathrm{~mm})$ and a late wetter winter-spring period $(380 \mathrm{~mm})$. Comps water table level are not impacted by the rainwater variations.

\subsection{Physico-chemical parameters}

Physico-chemical parameters show an overall contrasted signature between the three types of recharging water bodies: the Rhône's and the Gardon's surface waters and the limestone massif groundwaters.

Average temperatures for surface waters and limestone massif groundwaters are relatively close with an annual average of 15.4 and $15.0^{\circ} \mathrm{C}$ respectively. However, surface waters exhibit important variations over the year ranging from 6.4 to $28.9^{\circ} \mathrm{C}$, unlike the limestone massif groundwater which shows a narrower range of values between 12.0 and $20.8^{\circ} \mathrm{C}$. Comps alluvial groundwaters exhibits an intermediate signature with an average value of $17.0^{\circ} \mathrm{C}$, ranging from 13.0 to $20.0^{\circ} \mathrm{C}$.

Total Dissolved Solutes (TDS) shows similar contrasting results. Surface waters average TDS is $268 \mathrm{mg} / \mathrm{L}$ and ranging between 123 and $360 \mathrm{mg} / \mathrm{L}$ whereas limestone massif groundwaters shows higher and nearly steady values around $490 \mathrm{mg} / \mathrm{L}$. Comps groundwater TDS ranges between both surface waters and limestone massif groundwaters signatures in two distinct groups: the Comps western boreholes signature showing higher mineralization (close to $430 \mathrm{mg} / \mathrm{L}$ ) and the Comps eastern boreholes, with lower mineralization (around $294 \mathrm{mg} / \mathrm{L}$ ).

The dissolved oxygen (DO) content in surface waters is at equilibrium with the atmospheric oxygen content $\left(\mathrm{X}^{-}=10.1 \mathrm{mg} / \mathrm{L}\right)$. Limestone massif groundwater DO is slightly lower $(6.0$ and $7.9 \mathrm{mg} / \mathrm{L})$ while Comps water is even more depleted in DO, especially in the eastern boreholes, ranging from 0.6 to $3.3 \mathrm{mg} / \mathrm{L}$.

Hydrogen potential $(\mathrm{pH})$ is neutral to slightly basic. Surface water presents the highest $\mathrm{pH}$ values ranging between 7.0 and 8.5 , while limestone massif water $\mathrm{pH}$ is close to neutral showing only small variations (between 7.1 and 6.8). Comps alluvial groundwater exhibits an intermediate signature ranging between seven and eight.

\subsection{Water facies and major ions concentrations}

Data from fortnightly sampling are given in Table 1 (supplementary data). Major ion analyses, for all considered water bodies in the studied area, exhibit a typical $\mathrm{Ca}-\mathrm{HCO}_{3}$ fresh water type (Fig. 3.).

Despite a shared $\mathrm{Ca}-\mathrm{HCO}_{3}$ facies, water bodies still exhibit some contrast according to their origin: limestone massif waters present higher proportion of calcium and nitrate ions while surface waters exhibit higher proportion of magnesium and sodium ions.

The annual ion concentrations survey (supplementary data) confirms the contrasts between the different water bodies composition and their temporal variability:

Over the studied year, concentrations of calcium and nitrate ions are three to five times higher in the limestone waters than surface waters signature.

Those higher rates can easily be explained by dissolution of calcite for $\mathrm{Ca}^{2+}$ and local agricultural activities for nitrate ions.

Surface water exhibits higher fluctuations than the relatively steady limestone water signature. Sulfates, chlorides and sodium are the most concerned ions follow seasonal variations.

As shown before, Comps alluvial groundwaters plot between surface waters and limestone massif groundwaters.

\subsection{Water stable isotopic signature}

The Rhône river shows very depleted waters, with $\delta^{2} \mathrm{H}$ values ranging from $-57 \%$ o to $-75 \%$ vs. V-SMOW2, while the Gardon waters, in contrast, are much more enriched, with $\delta^{2} \mathrm{H}$ values ranging between $-34 \%$ and -22 vs. V-SMOW2 (Fig. 4). Rhône surface waters plot mainly along the Global Meteoric Water Line (GMWL: $\delta 2 \mathrm{H}=8.13 \delta^{18} \mathrm{O}+10.8$ Craig, 1961; Rozanski et al., 1992). Gardon's water signatures plot along the Local Meteoric Water Line - LMWL (Ladouche et al., 2009). For simplification purposes, $\delta^{18} \mathrm{O}$ and $\delta^{2} \mathrm{H}$ following relatively similar trends, $\delta^{2} \mathrm{H}$ data will be considered hereinafter, since it is the most discriminant parameter of both. 


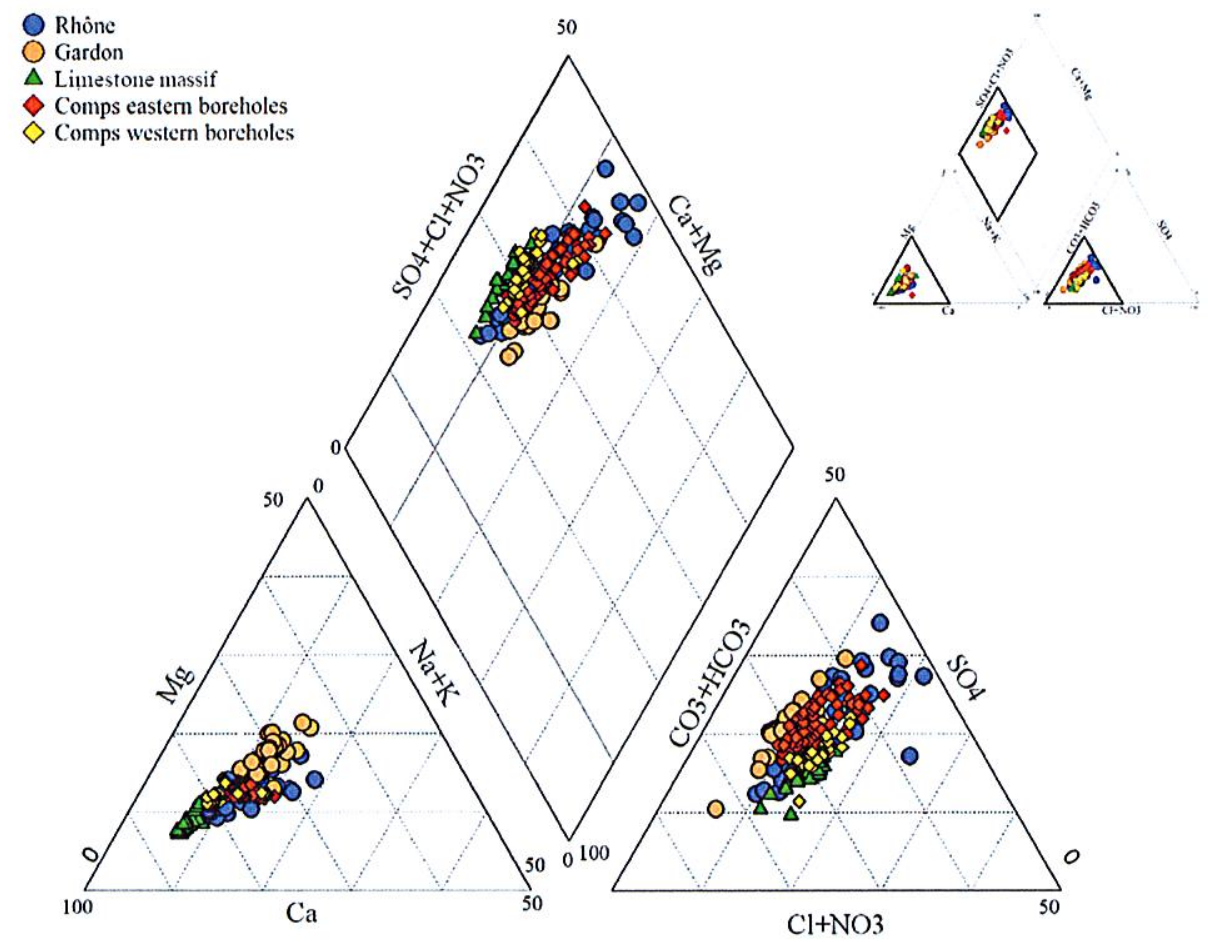

Fig. 3. Piper's diagram of studied waters in the area.

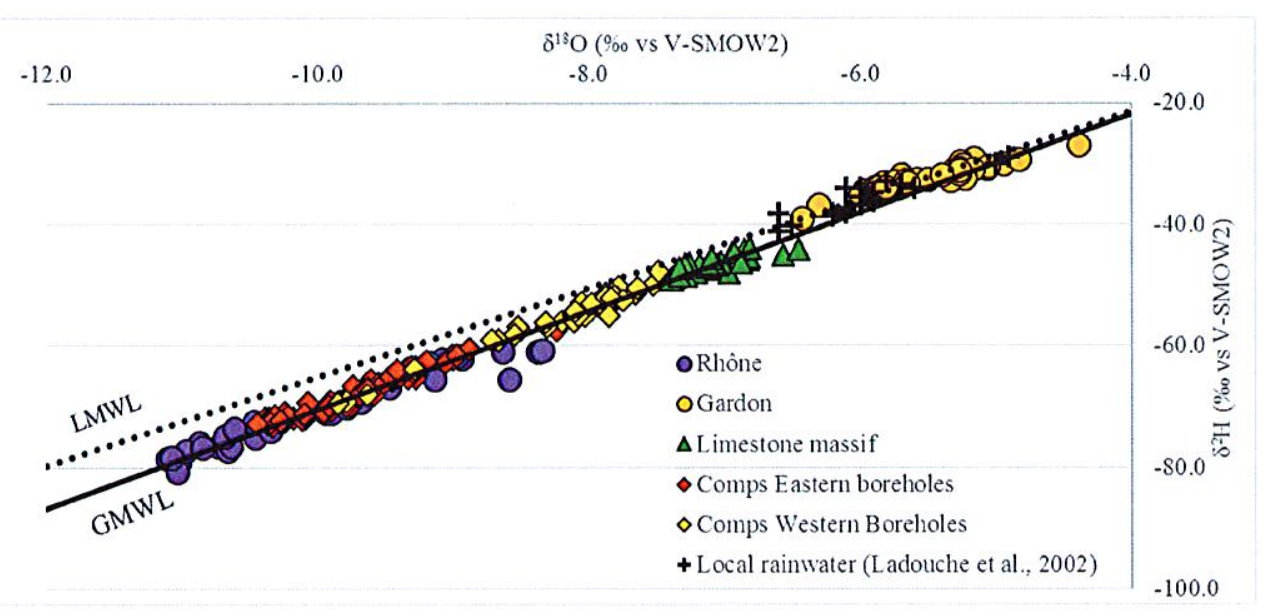

Fig. 4. $\delta^{18} \mathrm{O}$ vs. $\delta^{2} \mathrm{H}(\%$ vs. V-SMOW2) diagram. The GMWL is plotted in straight line and the LMWL in dotted line (local rainfall values Ladouche are also displayed from Ladouche et al., 2002).

With rainfall brought by runoff from higher latitude and altitude catchment areas, the Rhone relatively depleted signatures are expected (Rozanski et al., 1992). The Rhone river signature varies widely over the studied year (Fig. 4). The observed seasonal variations can be related to varying contribution of the different catchment areas according to seasons.

In contrast, the Gardon river narrowed and enriched values are expected due to a smaller catchment area and the proximity to the Mediterranean Sea.

Limestone massif signature exhibits an intermediate steady isotopic signature, with $\delta^{2} \mathrm{H}$ ranging between $-45 \%$ and $-40 \%$. Values are consistent taking account local precipitation as well as Rhône river recharges.

Similarly, as for physicochemical parameters and major ions analysis, Comps alluvial groundwaters signature falls in between surface waters (eastern boreholes) and limestone massif groundwaters (western boreholes) signatures. $\delta^{18} \mathrm{O}$ and $\delta^{2} \mathrm{H}$ followed similar trends, $\delta^{2} \mathrm{H}$ data will be considered hereinafter, for simplification purposes, since it is the most discriminant parameter of both.

\subsection{PCA and binary tracers' diagrams}

In order to extract from all collected data, insights on the different waters bodies' contribution to the Comps aquifer recharge, principal component analyses (PCA) is carried out using XLSTAT Software. PCA main interest is to reduce variability induced by numerous parameters of a large data set to a smaller set of artificial principal components (Wold et al., 1987).

The analysis combines 9 variables $\left(\delta^{2} \mathrm{H}, \delta^{18} \mathrm{O}, \mathrm{Na}^{+}, \mathrm{Ca}^{2-}, \mathrm{K}^{+}, \mathrm{Cl}^{-}\right.$, $\mathrm{Mg}^{2+}, \mathrm{HCO}_{3}^{-}, \mathrm{NO}_{3}^{-}, \mathrm{SO}_{4}^{2-}$ ) including both major elements and stable 
isotopes data for a total of 275 water samples from Table 1, including limestone massif groundwaters, surface waters and Comps groundwaters.

Two factors, used for interpretation, explain $70 \%$ of total variability (F1 $=45 \%$; F2 $=25 \%$ ).

The first axis is mainly defined by major elements $\left(\mathrm{Na}^{+}, \mathrm{Ca}^{2+}, \mathrm{K}^{+}\right.$, $\mathrm{Cl}^{-}, \mathrm{Mg}^{2+}, \mathrm{HCO}_{3}^{-}, \mathrm{NO}_{3}^{-}, \mathrm{SO}_{4}^{2-}$ ) positively correlated with the water mineralization, while the second axis is defined by the water stable isotopes signature $\left(\delta^{2} \mathrm{H}, \delta^{18} \mathrm{O}\right)$.

Plotted on the PCA diagram the Rhône, Gardon and limestone water, are well identified in three differentiated groups of water (see Fig. 5):

- Low to lightly mineralized waters $\left(\mathrm{X}^{-}=-1.1 ; \sigma=1.1\right)$ and with enriched water stable isotope signature $(\bar{Y}=2.7 ; \sigma=0.5)$ corresponding to the Gardon river waters;

- Slightly mineralized water $\left(\mathrm{X}^{-}=-1.1 ; \sigma=1.3\right)$ and depleted water stable isotope signature $(\bar{Y}=-1.0 ; \sigma=1.3)$ the Rhône surface waters;

- Water with higher mineralization $\left(\mathrm{X}^{-}=3.1 ; \sigma=0.6\right)$ and lightly enriched stable isotope signature $(\bar{Y}=1.1 ; \sigma=0.6)$ corresponding to limestone massif waters.

For Comps alluvial groundwaters, PCA define two distinct groups:

- Low to lightly mineralized water $\left(\mathrm{X}^{-}=-0.8 ; \sigma=0.6\right)$ and depleted water stable isotope signature $(\bar{y}=-0.9 ; \sigma=0.8)$ : this group correspond to the water boreholes from the eastern border of the Comps well field.

- Medium to mineralized waters $\left(\mathrm{X}^{-}=2.8 ; \sigma=0.8\right)$ and intermediate water stable isotope signature $(\bar{y}=0.1 ; \sigma=0.4)$ : this group corresponds to the water boreholes from the western border of the Comps well field.

Therefore, PCA data processing indicates two dominant influences on the alluvial Comps groundwater, a major Rhône river contribution for eastern boreholes and a mixing process between limestone massif waters and Rhône river for western boreholes.

PCA results indicate a limited Gardon river contribution. Those trends are also evident on the $\mathrm{Cl}^{-}, \mathrm{Ca}^{2+}, \mathrm{NO}_{3}^{-}$vs $\delta^{2} \mathrm{H}$ diagrams which, over other parameters, show good contrast between the potential contributors (Fig. 6).

Those diagrams also provide additional information on potential reactive processes:

At the Comps eastern boreholes, a small calcium ions enrichment with respect to the Rhone water is revealed. This enrichment could be explained either by a slight limestone massif water contribution or by a mineralization process during water flow through the alluvial aquifer.

In addition, Comps eastern boreholes waters are also concerned by nitrate ions loss. Denitrification process due to bacteria activity during water flows through the bank and the aquifer could provide a suitable explanation (Grischek, 1998).

Hence, results indicate that a combination of mixing and reactive processes could explain the Comps groundwater quality.

In order to evaluate those processes over time and space, two models will be used: the GLUE-EMMA model, which defines all potential conservative mixing process with the associated end-members contribution likelihood, and the PHREEQC inverse modeling, which accounts for chemical changes from the reactive process.

\subsection{Mixing models}

\subsubsection{GLUE-EMMA conservative mixing model}

4.6.1.1. Model parameters. In literature, the most commonly applied tracers in mixing studies are $\mathrm{Ca}^{2+}, \mathrm{Mg}^{2+}, \mathrm{K}^{+}, \mathrm{Na}^{+}, \mathrm{Cl}^{-}, \mathrm{CO}_{3}^{2-}, \mathrm{NO}_{3}^{-}, \delta^{2} \mathrm{H}$ and $\delta^{18} \mathrm{O}$ with a minimum of $\mathrm{n}$ tracers for $\mathrm{n}+1$ end-members. (Barthold, 2011; James, 2006; Hooper, 2003).

In our study, to pursue mixing calculation between the three endmembers, the limestone massif waters, the Gardon and the Rhône surface waters, two conservative, contrasted and independent tracers would be sufficient. In our set of parameters, $\mathrm{Cl}^{-}$and $\delta^{2} \mathrm{H}$ are the most relevant tracers as their conservative behavior is well studied in literature and the observed contrast between endmember signatures is significant. However, owing to the temporal viability of the end-member signature, the resulting part of mixing are not constrained enough, varying between 20 and $60 \%$. A central feature of GLUE-EMMA is its capability to use more tracers than necessary to validate a model and constrain results. Hence, $\mathrm{Ca}^{2+}$ ions, as part of the discriminant elements according to PCA and binary diagrams, is considered as a potential third conservative tracer. The hypothesis that $\mathrm{Ca}$ is conservative will be

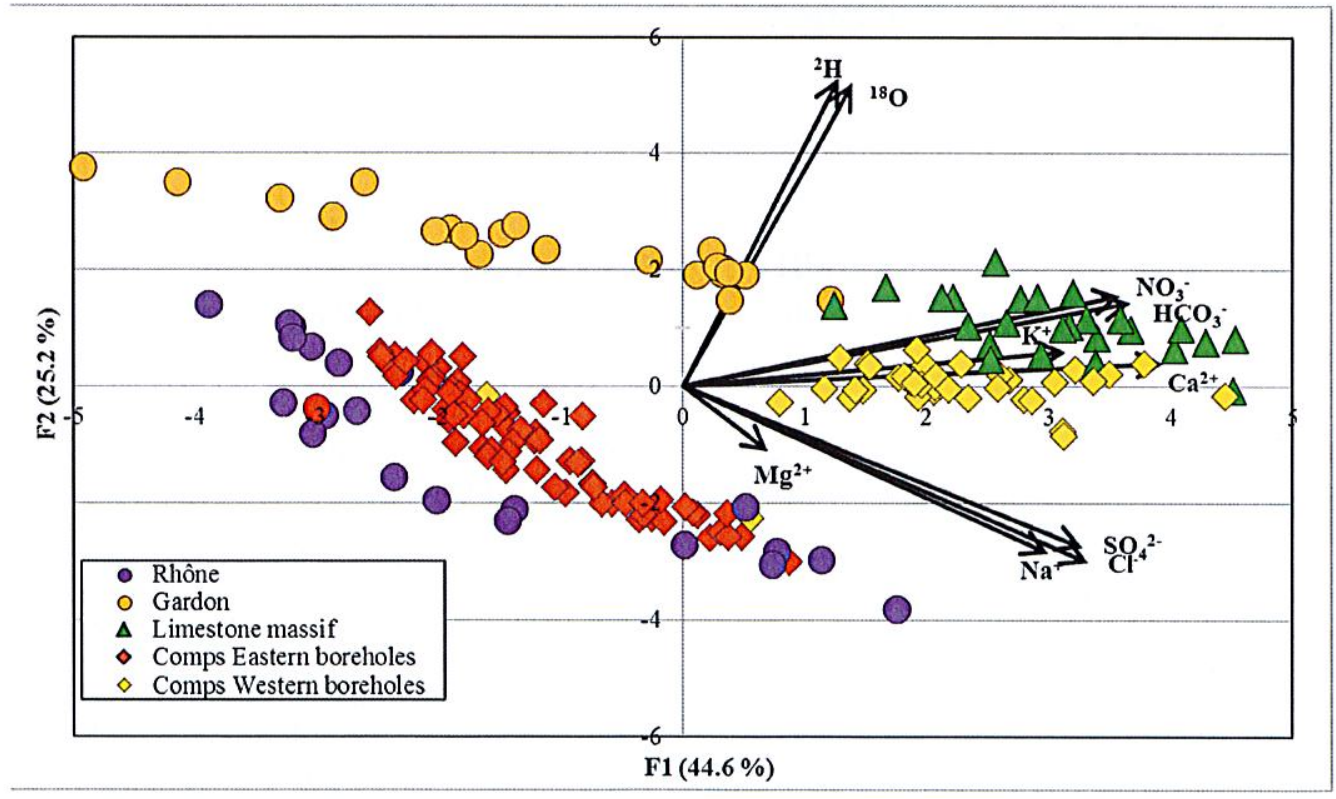

Fig. 5. Principal Component Analysis diagram. 

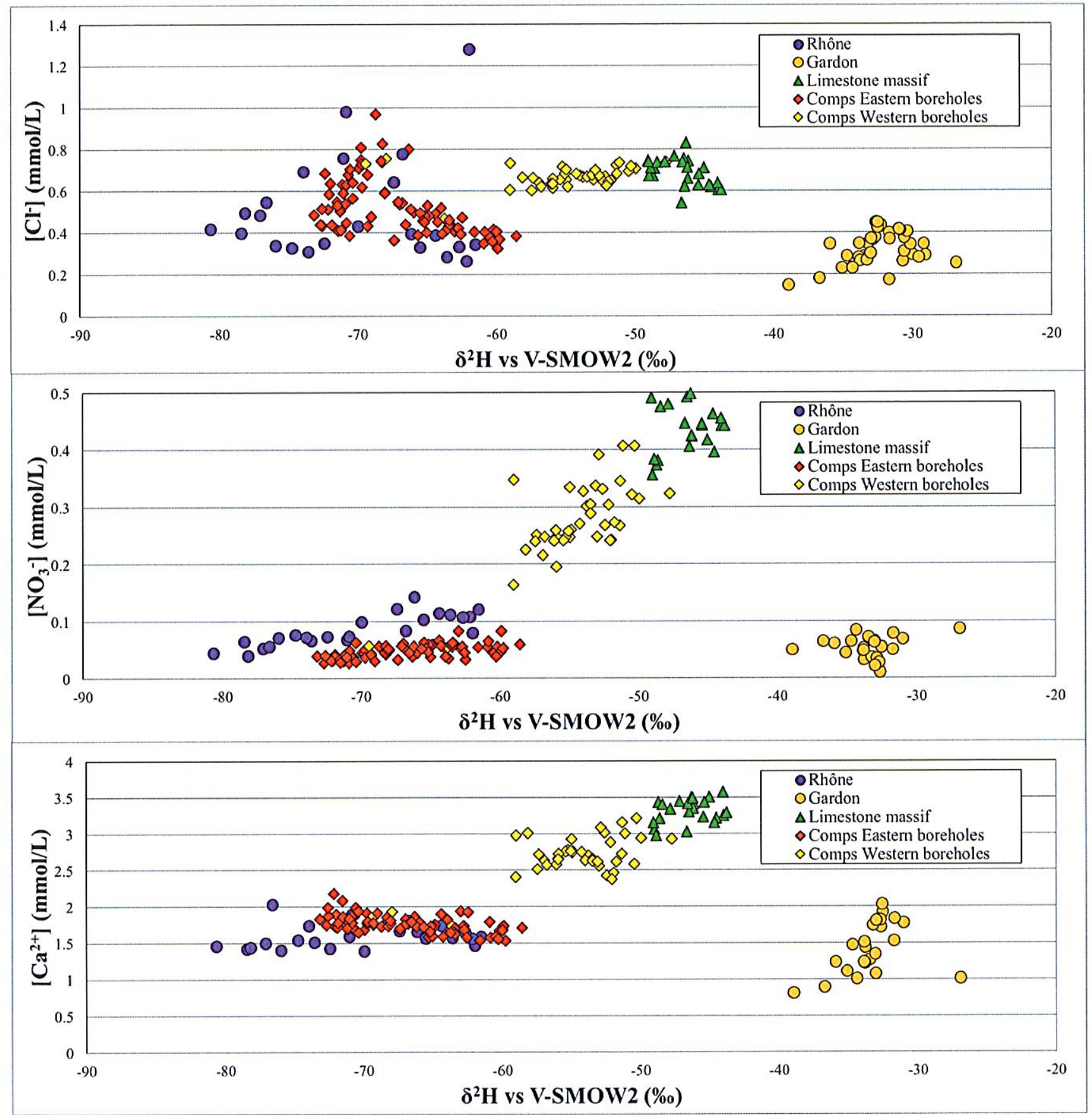

Fig. 6: Binary diagrams: $\mathrm{Cl}-, \mathrm{NO} 3-, \mathrm{Ca} 2+$ vs $\delta 2 \mathrm{H}$ vs V-SMOW2

Fig. 6. Binary diagrams: $\mathrm{Cl}^{-}, \mathrm{NO}_{3}^{-}, \mathrm{Ca}^{2+}$ vs $\delta^{2} \mathrm{H}$ vs V-SMOW2.

further investigated, in the following section, using PHREEQC model.

As explained above, GLUE-EMMA's main interest lies on its capacity to integrate end-members temporal variations as well as and analytical result uncertainties to validate a mixing model.

As input to the model, an analytical uncertainty of $=5 \%$ for the major ions and $0.5 \%$ of derterium, was considered for each analysis. Along with this uncertainty, a time window needs to be wisely set to constrain the time variant end member signatures.

According to the last borehole permeability measurement (K), aquifer materials porosity $(20 \%)$ and the hydraulic gradient between end-members and Comps boreholes, various flow paths may be engaged which span travel times in the order of few days to 40 days (see

The transfer times calculated below correspond to a rough estimate of the shortest pathway. Perpendicularly from Comps boreholes to the river bank and the shallow limestone massif bounds, it is therefore the smaller possible transfer time. Longer pathways, and therefore a longer transfer time, around the cone of depression needs to be envisaged. Moreover, permeability values have probably reduced since 1993 and need to be reconsidered. Indeed, transmissivity already fell sharply from $60 \%$ to $80 \%$ between 1976 and 1993 (Plagnes, 1994). These decreases can be explained by local clogging in the immediate environment of the studied boreholes or on a larger scale, along the river banks. 
Based on this estimate, time variant end members signature was defined with the range of the measured concentrations observed during either the last 60,30 or 15 days before each considered groundwater sampling collection date. Thus, three specific model configurations were defined for each one of the 26 sampling campaigns, including:

\section{- The Comps ground waters measured at a sampling date \\ - The time variant end member's signature (60, 30 or 15 days). Those end members signatures are defined with the minimum, average, maximum and standard deviation of the measured concentrations over the considered period.}

Overall, for each time window, a set of 26 distinct model configurations of $10^{8}$ Monte Carlo runs were pursued.

Mixing models are accepted when simulated results fall within $\pm 5 \%$ for the major ions and $0.5 \%$ for deuterium. Then, based on the uniform distribution of suitable mixing model results, likelihood of all component contribution is calculated.

4.6.1.2. Model results. Based on the positive fits for $\mathrm{Cl}^{-}, \mathrm{Ca}^{2+}$ and $\delta^{2} \mathrm{H}$ tracers for the 60 days end-members time variant simulations, GLUEEMMA resulted in an average of $5.3 \times 10^{4}$ suitable models, out of a possible $10^{8}$ runs, for 107 of the 113 Comps groundwater samples (Table 3 -supplementary data).

Note that, 9 of them yielded suitable models only if the defined uncertainty on $\mathrm{Cl}^{-}$and $\mathrm{Ca}^{2+}$ is set at $10 \%$. Finally, only 6 samples yielded to no suitable models.

The last Comps groundwaters that could not be simulated are exclusively PN4's waters between March and May 2018. For those samples, suitable models are yielded when the time window of the endmembers signature are increased from 60 days to 100 days. This longer time travel is temporary engaged but still essential. For the 6 concerned groundwaters, this flexibility is considered acceptable without nonetheless distorting the targeted compositions. Thus, with acceptable relaxed constraints, all Comps groundwaters managed to be simulated.

Those constraints define the initial model's capacity to generate suitable models.

With time variant end-member reduced to 30 days and 15 days, fitting constraints increase and simulations lead to too many situations with no solution.

Over the 113 Comps groundwaters, suitable models are generated for 74 and 57 of them respectively, with eastern boreholes groundwaters the most impacted. The remaining suitable models did not exhibit significate different composition with the 60 days time variant endmembers simulations.

Hence, the 60 days time variant end-members simulation results are hereinafter considered as it is essential to include short-term as well as long-term flow paths in order to simulate all waters.

Based on the results, a conservative mixing process of the three considered end-members, the limestone massif groundwater and the Gardon and Rhône surface water, appears sufficient to account for the majority of the observed groundwater quality as well as the calcium ions enrichment observed for the eastern boreholes.

The modeled parts of mixing distributions for the different samples are plotted on Fig. 7, with their calculated likelihood represented by the median values (dark colored marker) and the 5-95 and 25-75 percentile ranges (shaded and colored bands). Based on distribution of median and inter quartile of suitable models, end-members variability is narrowed between 10 and $20 \%$.

For the eastern Comps boreholes (PNord/PN4/PA1), the average of the median component contributions is $85 \%$ of Rhone water, $9 \%$ of limestone waters and $6 \%$ of Gardon waters.

Those contributions tend to vary along the year showing a higher Rhône river contribution between October and April, reaching 90 to

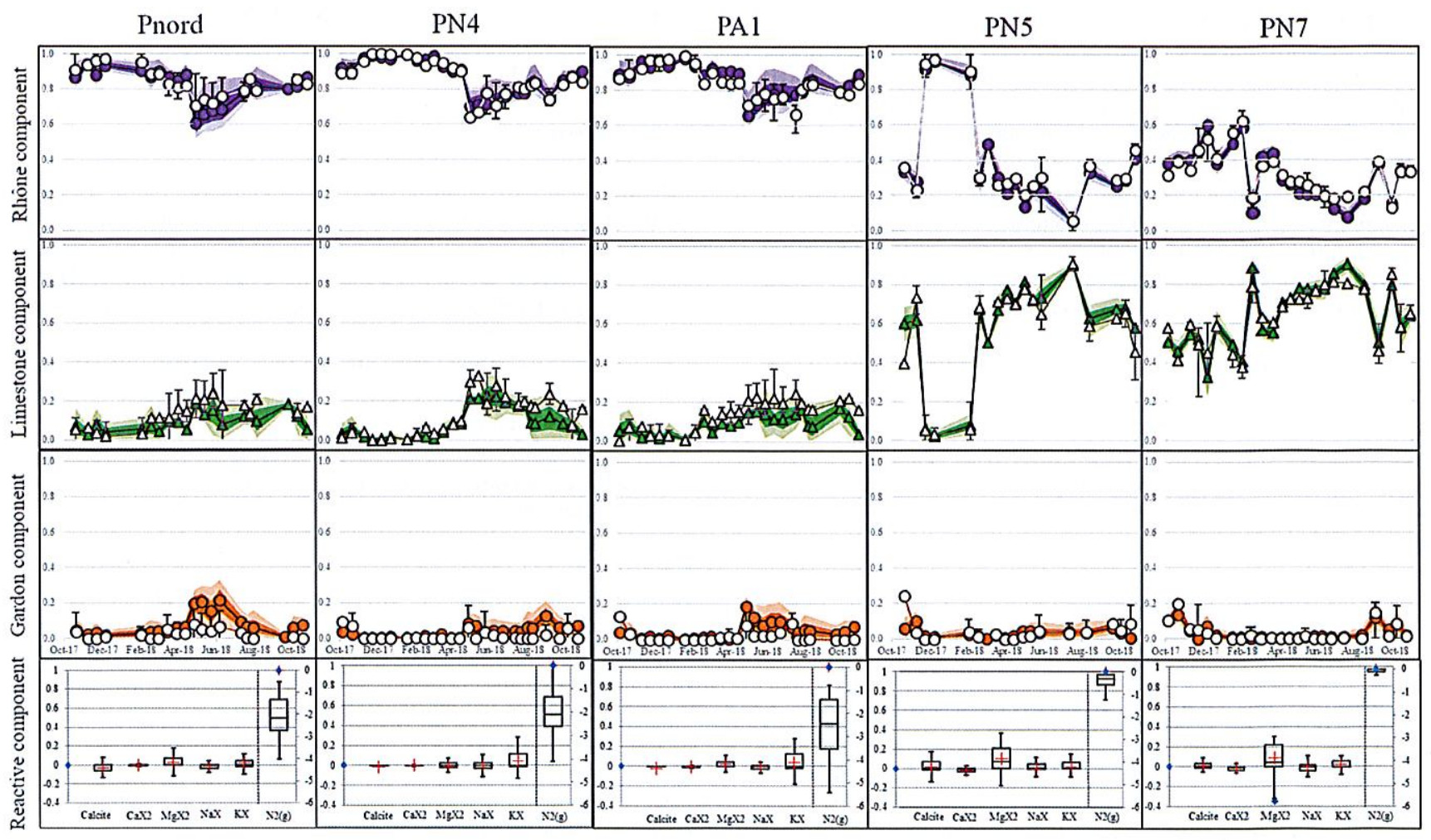

Fig. 7. GLUE-EMMA median (dark colored marker), 25-75 percentile range (dark-colored band), and 5-95 percentile range (light-colored band) of components contributions; PHREEQC average (light colored marker) with minimum and maximum (error bars) of components contributions, bloxplots of reactive processes with minimum, maximum (blue diamonds) and average (redcross) relative fluxes contribution. $\mathrm{N} 2(\mathrm{~g})$ fluxes are displayed on secondary axis. (For interpretation of the references to color in this figure legend, the reader is referred to the Web versior. of this article.) 
nearly $100 \%$, before a decrease for the rest of the year down from 70 to $60 \%$.

Regarding the western boreholes (PN5/PN7), the average median component contributions are $58 \%$ of limestone waters, $37 \%$ of Rhône waters and only $5 \%$ of Gardon waters. The limestone component contribution trends to increase between April and October, reaching $80 \%$ in summer period.

Moreover, at the PN5 borehole, the water composition changes suddenly from December to February 2018. During this period, simulations exhibit a very high Rhône water contribution ( $92 \%$ average median) before PN5 composition restores to its precedent behavior (Rhône water contribution lower than 40\%).

\subsubsection{PHREEQC reactive inverse model}

4.6.2.1. Model parameters. As indicated above, combination of mixing and reactive process could explain the Comps groundwaters quality.

The main interest in using PHREEQC is to account for the chemical changes that occur as the solutions equilibrate after mixing and as reactive processes occur in the alluvial reactive environment.

In the inverse modeling procedure, we consider the same three endmembers, the set of known conservative tracers $\left(\mathrm{Cl}^{-}, \delta^{2} \mathrm{H}\right)$ and the complementary set of ions, with a potentially reactive behavior $\mathrm{Ca}^{2+}$, $\mathrm{K}^{+}, \mathrm{Na}^{+}, \mathrm{Mg}^{2+}, \mathrm{SO}_{4}^{2-}, \mathrm{HCO}_{3}^{-}, \mathrm{NO}_{3}^{-}$.

Here, $\mathrm{Ca}^{2+}$ is set free to be engaged in reactive process. Hence, its conservative behavior will be evaluated along with its legitimate use in the GLUE-EMMA model.

PHREEQC inverse modeling requires the characterization of uncertainties for each element input and output. Hence, in agreement with the parameters used in GLUE-EMMA model, the composition of the time variant end members is defined by the range of composition observed during the 60 days period before each sampling date. We set the variability of each analysis to their respective analytical uncertainty ( $\pm 5 \%$ for major ions and $0.5 \%$ ofor deuterium).

Hence, models input files consist of 26 batchs of field-measured $\mathrm{pH}$, concentrations of major ions and water stable isotope signatures, described by their mean and the associated uncertainties (based on minimum and maximum values over the period).

Regarding the reactive process, cationic exchange (KX/Ca2X/Mg2X/ $\mathrm{NaX}$ ) and calcite mineral dissolution/precipitation were considered as reactive phases, in agreement with the aquifer material. Nitrate attenuation and nitrogen production in the aquifer may occur vial bacterial heterotrophic denitrification. To simulate those processes, N2(g) output along with $\mathrm{CHO}$ input, as organic matter, are accounted as additional phases.

The inverse models were run using the phreeqc.dat data base, which defines rate expressions, stoichiometric and thermodynamic properties of all of the aqueous phase species, exchange species, surface species, and pure phases.

Output files provide for each suitable solution which respect uncertainty constraints and ionic balance, the contributions of the endmembers and the associated reactive phases.

4.6.2.2. Models results. PHREEQC inverse modeling yield to simulate 90 of the 113 COMPS groundwaters within initial parameters. 17 samples yielded suitable models only if the defined uncertainty on elements balance is set at $10 \%$. Only six groundwater samples yielded to no inverse model fitting either due to the water balance misfit and/or to the uncertainty constraints. Simulation yields on average 25 distinct models for each Comps groundwaters. All suitable models include only a few different end-members mixing combinations (average of five). Each one of them is combined with different reactive phase inputs.

The results are described in output files with the end-members part of mixing and the associated reactive phases contributions.

Regarding the end-member result combinations, minimum, average and maximum end-members contribution are used to display the results range. Parts of mixing computed with the PHREEQC model exhibit similar results as GLUE-EMMA's: the Rhône river average contribution in the Eastern comps boreholes (PNord/PN4/PA1) is $84 \%$, while in western boreholes (PN5/PN7) the Rhône and limestone massif waters part of mixing are 36 and $61 \%$ respectively. Those contributions evolve over the studied year for each borehole in accordance with the GLUEEMMA's results.

Considering the full range of possible values, the calculated contributions vary only slightly, ranging between 10 and $20 \%$ across all models' outputs. However, variability of plausible models is more or less narrowed depending on the simulated waters.

Regarding the reactive phase's contributions, the ion concentration, which leave (negative value) or enter (positive value) the simulated solution, are provided in Table 3. The highest input is for $\mathrm{Ca}^{2+}$ due to calcite dissolution/precipitation with an average flux in the order of $0.01 \mathrm{mmol}(\sigma=0.15)$ ranging from -0.4 to $+0.7 \mathrm{mmol}$. The fluxes of the $\mathrm{Na}, \mathrm{K}, \mathrm{Mg}$ cations and nitrates are 2-20 times lower than that of $\mathrm{Ca}$ and remain below $0.2 \mathrm{mmol} / \mathrm{L}$. However, the significance of each reactive flux needs to be accounted with respect to the initial concentrations of the simulated solution.

Hence, the relative contribution of each flux across the ground waters composition are calculated and displayed as boxplot in Fig. 7 .

Mainly, the most significant relative inputs are that of $\mathrm{K}^{+}$and $\mathrm{Mg}^{2+}$. Those cations are engaged in all models in non-negligible proportions ranging between $-10 \%$ and $+16 \%$ for $\mathrm{K}+$ and $-14 \%$ to $+23 \%$ for $\mathrm{Mg}^{2+}$. In contrast, $\mathrm{Na}^{+}$and $\mathrm{Ca}^{2+}$ fluxes are less significant: $\mathrm{Ca}^{2+}$ flux range between -5 and $+4 \%$, and $\mathrm{Na}^{+}$between -6 and $5 \%$. Those fluxes are quite small and falls within the acceptable uncertainties set for the models. Hence in the GLUE-EMMA's model $\mathrm{Ca}^{2+}$ can be considered as a conservative tracer within the given constraints. On the other hand, $\mathrm{NO}_{3}^{-}$ output fluxes range between 0 and $500 \%$ of remaining measured concentrations. Indeed, $\mathrm{N} 2(\mathrm{~g})$ phase is particularly engaged for PA1, PN4 and Pnord groundwater rather than PN5 and PN7.

\section{Discussions and conclusions}

\subsection{Mixing models}

Mixing models are powerful tools which allow the run of multiple scenarios and provide a range of possible solutions that are useful for characterizing hydrological systems and for decision-making processes (Soulsby et al., 2003a; Uhlenbrook and Hoeg, 2003). They offer valuable information if determinant parameters such as uncertainties and reactive process are adequately accounted for. The main issues in our study are to constrain mixing models with the time variability of the endmembers signatures, mainly observed with surface waters, while accounting for potential reactive mixing processes.

GLUE-EMMA was used as a powerful statistical tool which define each suitable conservative model mix and calculate likelihood of each component contribution. A central feature of GLUE-EMMA is to use more tracers than necessary which helps with constraining the results. For this study, the three end-members mixing model solutions were generated by combining the two minimum required conservative tracers, $\mathrm{Cl}^{-}$and ${ }^{2} \mathrm{H}$, with $\mathrm{Ca}^{2+}$, to narrow the results variability.

Along GLUE-EMMA models, PHREEQC inverse modeling was used to assess reactive processes occurring during flow path and their influence in the Comps groundwater quality variations. With respect to the aquifer material, cation exchange, calcite dissolution/precipitation and denitrification process were considered. Moreover $\mathrm{Ca}^{2+}$ conservative behavior is be confirmed and with it, its pertinence as a GLUE-EMMA model tracer along with $\mathrm{Cl}^{-}$and ${ }^{2} \mathrm{H}$.

One of the key parameters to narrow both models' results is to constrain the end-member time variant signatures with respect to the apparent travel times of the multiple flow paths. A 60 days time window optimum was considered, based on hydraulic parameters and capacity 
of models to fit. This required time window for the models provides further information on the groundwater travel time confirming a minimum of 60 days for the longest flow path. This is consistent with a permeability decrease since their last estimate in 1993. Hence with two distinct approaches, both the GLUE-EMMA models and PHREEQC inverse models provide coherent results accounting for time and space variability of the Comps ground waters quality. This application illustrates the interest in using a combination of complementary models based on suitable and verified hypotheses to the management of the water supply resource.

\subsection{Comps water resource management}

The observation and model results shed some light on the Comps groundwater mechanisms. The Comps groundwater quality can be explained by mixing process dominated by the Rhône river waters and limestone massif waters.

Therefore, the variation of the Comps ground waters quality is influenced by the end-member seasonal signature.

The model's configuration provides some insight to constrain the time travel along the flow path. The minimum required time window for the successful application of models, here 60 days, is an indicator of the time travel. This insight is pertinent in relation with end-members which show significant variation in the water signature, here the Rhone river. As the main recharge, its variability will be transmitted to the groundwater composition with a delay which is used as the main discriminant factor. In this study, this application has an interest for the eastern boreholes, which are mainly fed by the Rhône river waters with a highest signature variation.

In first instance, the Rhône river and limestone massif influence are strongly linked to the Comps boreholes distance from the end-members. Variations of the mixing process over the year can be explained by the competition between the two main end-member's influence on the Comps aquifer. This competition is potentially ruled by the Rhone river and Limestone massif relative capacity to feed the aquifer according to their individual high and low water periods. Those periods depend on the recharges for the Limestone massif, on one hand, and the Vallabregues dam water release for the Rhone river, on the other hand. Those seasonal parameters are most likely responsible for the Rhône river and limestone massif contribution trends exhibited during the first and second half of the studied period.

Variations of the mixing process could also be related to changes in the pumping regime of the selected boreholes between the sampling campaign dates. As exposed by the pumping rates survey, alternative pumping regimes are often set up. This modify the borehole zones of influence and therefore the end member solicitations. Remnants of those effects could still be significant on sampling campaign dates even though the pumping configuration was always the same at the time of sampling.

This interfering configuration could explain the complete and sudden signature modification exhibited by the western PN5 borehole from December to February.

Along with conservative mixing processes, PHREEQC models indicate that non negligible relative fluxes of $\mathrm{Mg}^{2+}$ and $\mathrm{K}^{+}$are needed to fit with the required constraints for each Comps groundwater simulation. More over significant $\mathrm{NO}_{3}^{-}$output fluxes are accounted for eastern boreholes groundwaters. A consistent denitrification process considering their depleted dissolved oxygen concentrations. PHREEQC models also confirm the relative conservative behavior of $\mathrm{Ca}^{2+}$ ions and legitimate its use in GLUE-EMMA conservative models.

\section{Conclusions}

This study exposed the interest in a small dynamic aquifer to combine GLUE-EMMA and PHREEQC models. Both help to define the main factors influencing the groundwater quality variations and assess the most likely models.
Successful application and combination of those models lies on key parameters. In our study it may be attributed to the small size of the studied site, chemical contrast between end members, strong seasonal signals and a close monitoring.

Understanding in detail the mechanisms of the well field is essential to manage the current and futures pressures. As we showed that the Rhône river is the main source of recharge water to the Comps well field, predominant with respect to the other two sources the Gardon river and the Karst aquifer, it has implications in terms of both quantity and quality for the water resource.

Indeed, the Rhône river flows through a strongly anthropized environment and collect a variety of industrial, urban, agricultural effluents. Hence the Rhône river brings contaminants that can be transferred to the well field and this risk needs to be address. In addition, due climate change impacts, by 2060 the Rhône river water level is expected to decrease by $30-70 \%$ in summer when the water supply demand is the highest of the year (Chauveau et al., 2013; Huss, 2011; Jean-Baptiste, 2020). Hence the risk of decreasing recharge to the Comps well field in future summer need to be addressed.

\section{Funding}

This work was supported by the French Ministry of Research and Education, and by Nimes Métropole Agglomeration.

\section{Declaration of competing interest}

The authors declare that they have no known competing financial interests or personal relationships that could have appeared to influence the work reported in this paper.

\section{Acknowledgements}

This work benefited from J. JEAN-BAPTISTE. PhD scholarship from the French Ministry of Research and Education, and from support by Nimes Métropole Agglomeration and the laboratory "Géochimie ISotopie environnementale" (Labo G.I.S) through the research team of CHROME.

\section{Appendix A. Supplementary data}

Supplementary data to this article can be found online at https://doi. org/10.1016/j.apgeochem.2020.104700.

\section{References}

Barthold, F.K., Tyralla, C., Schneider, K., Vaché, K.B., Frede, H.-G., Breuer, L., 2011. How many tracers do we need for end member mixing analysis (EMNA)? A sensitivity analysis. Water Resour. Res. 47, W08519 https://doi.org/10.1029/2011WR010604.

Benedicto, A., Labaume, P., Séguret, M., Séranne, M., 1996. Low-angle crustal ramp and basin geometry in the Gulf of Lion passive margin: oligocene-Aquitanian Vistrenque graben, SE France. Tectonics 15 (6), 1192-1212. https://doi.org/10.1029/ 96TC01097.

Chauveau, Mathilde, Chazot, Sébastien, Perrin, Charles, Bourgin, Pierre-Yves, Sauquet, E., et al., 2013. Quelsimpacts des changements climatiques sur les eaux de surface en France à l'horizon 2070? La HouilleBlanche - Revue internationale de l'eau 5-15. https://doi.org/10.1051//hb/2013027.meteo-00979. EDP Sciences.

Christophersen, Nils, Hooper, Richard, 1992. Multivariate analysis of stream water chemical data: the use of principal components analysis for the end-member mixing problem. Water Resources Research - WATER RESOUR RES 28, 99-107. https://doi. org/10.1029/91WR02518.

Craig, Harmon, 1961. Standard for Reporting Concentrations of Deuterium and Oxygen18 in Natural Waters, vol. 133. Science, New York, N.Y., pp. 1833-1834. https://doi. org/10.1126/science.133.3467.1833

Delsman, Joost, Essink, Oude, Gualbert, Beven, Keith, Stuyfzand, Pieter, 2013. Uncertainty estimation of end-member mixing using generalized likelihood uncertainty estimation (GLUE), applied in a lowland catchment. Water Resour. Res. 49, 4792-4806. https://doi.org/10.1002/wrcr.20341.

Garrels, Robert, Mackenzie, F., 1967. Origin of the Chemical Compositions of Some Springs and Lakes. https://doi.org/10.1021/ba-1967-0067.ch010.

Grischek, T., Hiscock, K.M., Metschies, T., Dennis, P.F., Nestler, W., 1998. Factors affecting denitrification during infiltration of river water into a sand and gravel 
aquifer in Saxony, Germany. Water Res. 32 (2), 450-460. https://doi.org/10.1016/ S0043-1354(97)00208-X, 0043-1354.

Hooper, R.P., 2003. Diagnostic tools for mixing models of stream water chemistry. Water Resour. Res. 39, 1055, https://doi.org/10.1029/2002WR001528,3.

Huss, M., 2011. Present and future contribution of glacier storage change to runoff from macroscale drainage basins in Europe. Water Resour. Res. 47, W07511 https://doi. org/10.1029/2010WR010299.

Jakeman, A.J., Barreteau, Olivier, Hunt, Randall, Rinaudo, Jean-Daniel, Ross, Andrew, Arshad, Muhammad, Hamilton, Serena, 2016. Integrated Groundwater Management: an Overview of Concepts and Challenges. https://doi.org/10.1007/ 978-3-319-23576-9_1.

James, A.L., Roulet, N.T., 2006. Investigating the applicability of end-member mixing analysis (EMMA) across scale: a study of eight small, nested catchments in a temperate forested watershed. Water Resour. Res. 42, W08434 https://doi.org/ 10.1029/2005WR004419.

Jean-Baptiste, J., 2020. Water stable isotopes and volumetric discharge rates to monitor the Rhòne water's seasonal origin. Heliyon. https://doi.org/10.1016/j. heliyon. 2020.e04376. In press.

Ladouche, Bernard, Aquilina, Luc, Dörfliger, Nathalie, 2009. Chemical and isotopic investigation of rainwater in Southern France (1996-2002): potential use as input signal for karst functioning investigation. J. Hydrol. 367, 150-164. https://doi.org/ 10.1016/j.jhydrol.2009.01.012.

Lapworth, D.J., Baran, Nicole, Stuart, M.E., Ward, R.S., 2012. Emerging organic contaminants in groundwater: a review of sources, fate and occurrence. Environ. Pollut. 163, 287-303. https://doi.org/10.1016/j.envpol.2011.12.034.hal00687127. Elsevier.

Margat, J., 2006. Exploitation des eaux souterraines. In: Aquifères et eaux souterraines en France. Sous la direction de J.C. Roux. Association Internationale des Hydrogéologues et BRGM, pp. 840-847. Orléans, France.
Parkhurst, David, Appelo, Tony, 1999. User's guide to PHREEQC version 3 - a computer program for speciation, batch-reaction, one-dimensional transport, and inverse geochemical calculations.

Penna, Daniele, Stenni, B., Anda, M., Wrede, Sirpa, Bogaard, T., Gobbi, A., Borga, Marco Fischer, Benjamin, Bonazza, Mattia, Chárová, Z., 2010. On the reproducibility and repeatability of laser absorption spectroscopy measurements for $\delta 2 \mathrm{H}$ and $\delta 180$ isotopic analysis. Hydrol. Earth Syst. Sci. 14, 1551-1566.

Pereira, Lílian, Souza, Alecsandra, Franco-Bernardes, Mariana, Pazin, Murilo, Tasso, Maria, Pereira, Paulo, Dorta, Daniel, 2015. A perspective on the potential risks of emerging contaminants to human and environmental health. Environ. Sci Pollut. Control Ser. 22 https://doi.org/10.1007/s11356-015-4896-6.

Plagnes, V., 1994. Identification des origines des eaux souterraines sur le champ de captage de Comps (Gard) par dosage d'éléments en trace et d'isotopes.

Rozanski, Kazimierz, Araguás-Araguás, Luis, Gonfiantini, Roberto, 1992. Isotopic patterns in global precipitation. J. Geophys. Res. 78 https://doi.org/10.1029/ GM078p0001.

Scanlon, Bridget, Jolly, Ian, Sophocleous, Marios, Zhang, Lu, 2007. Global impacts of conversions from natural to agricultural ecosystems on water resources: quantity versus quality. Water Resour. Res. 43 https://doi.org/10.1029/2006WR005486.

Scheili, Anna, Delpla, Ianis, Sadiq, Rehan, Rodriguez, Manuel, 2016. Impact of raw water quality and climate factors on the variability of drinking water quality in small systems. Water Resour. Manag. 30 https://doi.org/10.1007/s11269-016-1312-z.

Schwartz, Franklin, Ibaraki, Motomu, 2010. Groundwater: a resource in decline. Elements 7, 175-179. https://doi.org/10.2113/gselements.7.3.175.

Séranne, M., Benedicto, A., Truffert, C., Pascal, G., Labaume, P., 1995. Structural style and evolution of the gulf of lion oligo-miocene rifting : role of the pyrenean orogeny. Mar. Petrol. Geol. 12, 809-820.

Wold, S., Esbensen, K., Geladi, P., 1987. Principal component analysis. Chemometr. Intell. Lab. Syst. 2, 37-52. https://doi.org/10.1016/0169-7439(87)80084-9. 